\title{
1917 American Labor Union Support for Prison Education
}

\author{
THOM GEHRING
}

\author{
California State University, San Bernardino, United States
}

Industrial schools had been advocated by John Philbrick as early as 1861, for "a class of children, more or less numerous, which is too low down in the depths of vice, crime, and poverty, to be reached by the benefits of a system of public education" (Tyack, D.B. [1974]. The One Best System... Cambridge: Harvard U. Press. pp. 69-70). But by 1917, adopting more positive language, the U.S. Congress passed the Smith Hughes Act to help fund vocational education (Smith, Aker, and Kidd. [1970]. Handbook of Adult Education. NY: Macmillan, p. 474). The Smith Hughes Act resulted from the tenacious efforts of a coalition which included philanthropist/ industrialists, the National Association of Manufacturers, and chambers of commerce. Tyack wrote,

By 1910 the [vocational education] movement had won broad support, with endorsements from the NEA [National Education Association] and the American Federation of Labor (which had long been suspicious of the trade schools as sources of scab labor, but which apparently joined the movement in the hope of sharing in its control and improving the earnings of skilled labor) (Tyack, p. 189).

And in his 1931 book, The Education of Adult Prisoners, prison reformer Austin MacCormick announced the importance of this law in the process of developing institutional education services.

Thom Gehring is the research director of the Center for the Study of Correctional Education at California State University, San Bernardino. His scholarly emphasis is on the history of correctional education and prison reform. He has been a correctional educator since 1972. Thom did his Ph.D. dissertation on the correctional school district pattern of organization. He serves as the historian for the Correctional Education Association. Thom is a professor of education who directs the EDCA correctional and alternative masters degree program. 